\title{
Sejarah Penemuan Obat Baru Antivirus Zika (ZIKV)
}

\author{
Dwi Retno Sari \\ Program Studi Magister Farmasi, Fakultas Farmasi, Universitas Padjadjaran, Sumedang 45363 \\ email: dwi180232@mail.unpad.ac.id \\ (Submit 11/3/2019, Revisi 14/7/2019, Diterima 15/7/2019)
}

\begin{abstract}
Abstrak
Virus Zika (ZIKV) merupakan salah satu virus dari genus Falvivirus, dan ditularkan melalui gigitan nyamuk Aedes yang juga merupakan vektor penular penyakit arbovirus lainnya termasuk Demam Berdarah Dengue. Virus Zika diketahui menyebabkan gejala klinis ringan yang mirip dengan demam berdarah dan chikungunya dan ditularkan oleh spesies nyamuk Aedes yang berbeda. Namun komplikasi neurologis seperti sindrom Gullain-Barre pada orang dewasa dan anomali kongenital, termasuk mikrosefali pada bayi yang baru lahir dari ibu yang terinfeksi, menimbulkan kekhawatiran serius. Dalam mini review ini, dibahas terkait sejarah penemuan obat baru antivirus Zika.
\end{abstract}

Kata kunci : penemuan obat, antivirus, zika, falvivirus, nyamuk

\section{Outline}

- Pendahuluan

- Fleming Memulai Penemuan Obat Baru

- Penemuan Obat di Zaman Modern

- Penemuan Obat untuk Virus Zika

- Strategi Identifikasi ZIKV

- Kesimpulan

- Daftar Pustaka

\section{Pendahuluan}

Penemuan obat baru dimulai oleh Alexander Fleming sendiri terkenal karena dia merupakan ahli peneliti yang sangat pandai, tetapi ceroboh dan laboratoriumnya sendiri sering terlihat berantakan.

\section{Fleming Memulai Penemuan Obat Baru}

Tahun 1928, setelah pulang dari liburan panjang, Fleming baru teringat akan bakteribakteri dipiringan laboratorium lupa di simpan baik-baik, dan telah terkontaminasi dengan sejenis jamur. Beberapa piring laboratorium yang berisikan bakteri di buang, tetapi kemudian Fleming memperhatikan bahwa perkembangan bakteri pada daerah yang terkontaminasi oleh jamur tersebut menjadi terhambat. 
Fleming kemudian mengambil sampel contoh dari jamur tersebut dan menelitinya, dia menemukan bahwa jamur tersebut berasal dari genus Penicillium. Inilah sebabnya mengapa obat tersebut bernama penicillin atau penisilin (Indonesia).

\section{Penemuan Obat di Zaman Modern}

Kemudian dengan perkembangan zaman maka penemuan obat bukan lagi dengan kebetulan tetapi dilakukan dengan design atau dengan rancangan yaitu:

1. Menemukan Target Seleksi, untuk menentukan efek terapi obat yang akan berikatan dengan molekul.

2. Menentukan Senyawa Pemimpin (Lead Compound) agar dapat berikatan dengan reseptor.

3. Menggunakan Kimia Medisinal untuk perancangan senyawa terapeutik baru dan pengembangan menjadi obat yang berguna (Structure-Activity Studies, and in Silico Screening)

4. Study in-Vitro (Drug Affinity \& Selectivity, Celluler Disease Models, Mechanism of Action, and Lead Candidat Refinement)

5. Study in-Vivo (Animal Models, Behavioural Studies)

6. Trial Klinik dan Terapeutik untuk menentukan jangka panjang dalam penggunaan obat.

Selanjutnya dengan adanya penemuan obat menggunakan design atau rancangan, pilihan pengobatan baru sangat dibutuhkan. Oleh karena itu, menggunakan uji in vitro untuk menyaring pustaka terbatas senyawa organik kecil dan mengidentifikasi arahan bioaktif yang tinggi, dengan analog paling aktif menunjukkan aktivitas dalam kisaran pikomolar rendah.

\section{Penemuan Obat untuk Virus Zika}

"Hit" yang teridentifikasi memiliki fitur struktural umum tertentu yang dapat digunakan dalam desain generasi berikutnya dari inhibitor ZIKV.

Secara kolektif, temuan ini menunjukkan bahwa senyawa yang teridentifikasi mewakili templat yang sangat baik untuk pengembangan obat anti-Zika yang murah dan tersedia secara oral.

Virus Zika (ZIKV) merupakan salah satu virus dari genus Falvivirus, dan ditularkan melalui gigitan nyamuk Aedes yang juga merupakan vektor penular penyakit arbovirus lainnya termasuk Demam Berdarah Dengue. Kejadian luar biasa (KLB) pertama kali dilaporkan pada tahun 2007 di wilayah pasifik (Yap), kemudian dilaporkan beberapa kali KLB di wilayah Asia, Afrika, Regional Western Pasific, dan yang paling akhir terjadi di Amerika.

Pada sejumlah kecil kasus ditemukan bukti penularan melalui seksual dan vertikal (dari ibu ke anak), demikian juga dengan penularan melalui transfusi darah. 
Virus Zika diketahui menyebabkan gejala klinis ringan yang mirip dengan demam berdarah dan chikungunya dan ditularkan oleh spesies nyamuk Aedes yang berbeda. Namun komplikasi neurologis seperti sindrom Gullain-Barre pada orang dewasa dan anomali kongenital, termasuk mikrosefali pada bayi yang baru lahir dari ibu yang terinfeksi, menimbulkan kekhawatiran serius.

Dalam studi ini yaitu, mengeksplorasi efek penghambatan glikosaminoglikan dan analog terhadap infeksi ZIKV. Heparin sulfat, dekstran sulfat dan suramin secara signifikan menghambat infeksi ZIKV di sel Vero. De-sulfated heparin analog kehilangan efek penghambatan, menyiratkan bahwa kelompok sulfonat sangat penting untuk penghambatan virus. Suramin, obat anti parasit yang disetujui FDA, menghambat infeksi ZIKV dengan pengurangan viral load PFU 3-5\% dengan nilai IC50 2,5-5 $\mu \mathrm{g}$ I $\mathrm{ml}(1,93 \mu \mathrm{M}-3,85 \mu \mathrm{M})$.

Sebuah studi waktu-obat-tambahan mengungkapkan bahwa suramin tetap ampuh bahkan ketika diadministrasikan pada 1-24 jam. Suramin menghambat infeksi ZIKV dengan mencegah adsorpsi, entri dan replikasi virus.

Simulasi dinamika molekuler menunjukkan interaksi yang lebih kuat dari suramin dengan helikase ZIKV NS3 dibandingkan dengan protein amplop. Suramin menjamin penyelidikan lebih lanjut sebagai calon antivirus potensial untuk infeksi ZIKV.

Heparan sulfat (HS) adalah reseptor lampiran seluler untuk multiple flaviviruses. Namun, tidak ada interaksi ZIKV-heparin langsung yang diamati pada analisis pengikatan heparin, dan menurunkan regulasi atau penghilangan sel HS dengan natrium klorat atau heparinase I / III tidak menghambat infeksi ZIKV. Ini menunjukkan bahwa permukaan sel HS tidak digunakan oleh ZIKV sebagai reseptor lampiran, pada sofosbuvir, inhibitor polimerase nukleotida yang disetujui FDA untuk virus hepatitis $C$ yang jauh, dapat memiliki aktivitas antivirus terhadap infeksi ZIKV.

Studi kultur sel menetapkan bahwa sofosbuvir secara efisien menghambat replikasi dan infeksi beberapa strain ZIKV pada beberapa garis sel tumor manusia dan sel induk neuronal manusia yang diturunkan dari janin, sofosbuvir menghambat ZIKV dengan IC50 4 $\mu \mathrm{M}$, tetapi hanya pada sel Huh7. Ini berkorelasi dengan perbedaan konsentrasi intraseluler dari metabolit trifosfat aktif sofosbuvir, GS-461203 atau 007-TP, yang 11342 kali lebih tinggi pada sel Huh7 dibandingkan dengan sel Vero dan A549.

Kadar intraseluler 007-TP dalam jaringan dan jenis sel yang mendukung replikasi ZIKV in vivo harus ditentukan untuk menyelidiki lebih lanjut potensi sofosbuvir sebagai senyawa anti-ZIKV. Selain itu, pengobatan oral dengan sofosbuvir dilindungi terhadap kematian yang diinduksi ZIKV pada tikus. 


\section{Strategi Identifikasi ZIKV}

Tiga strategi umum telah diupayakan untuk mengidentifikasi inhibitor ZIKV:

- Repurposing obat klinis disetujui. Obat repurposing bertujuan untuk mengidentifikasi penggunaan baru dari yang sudah ada obat (atau senyawa dalam klinis pembangunan) untuk ZIKV terapi.

- Viral skrining fenotipik-replikasi berbasis inhibitor. Klon cDNA menular dan replikon telah dikembangkan untuk berbagai strain ZIKV. Ini sistem genetik sebaliknya dapat digunakan untuk memfasilitasi obat antivirus penemuan. sebagai rinci di bawah, reporter ZIKV dan replicon telah disesuaikan dengan tinggi-throughput skrining (HTS) senyawa perpustakaan.

- Penemuan obat Target dari virus protein. Itu Strategi berbasis sasaran telah menggunakan tiga umum Pendekatan: virus enzim berbasis HTS, struktur berbasis desain rasional, dan in silico docking Ini pendekatan telah sangat didukung oleh struktural Informasi dari ZIKV, termasuk itu cryo-EM struktur virion. Dan atom struktur protein virus individu, termasuk kapsid amplop, NS1, NS3, dan NS5

Hasil ini menunjukkan bahwa sofosbuvir mungkin menjadi kandidat untuk evaluasi lebih lanjut sebagai terapi terhadap infeksi ZIKV pada manusia.

Menurut keterangan-keterangan diatas diharapkan sofosbuvir lebih dikembangkan lagi untuk menjadi senyawa anti-ZIKV yang baik dan diperjual bebas agar masyarakat yang terkena zika virus dapat di minimalisir.

\section{Kesimpulan}

Seiring dengan perkembangan zaman, penemuan obat bukan lagi melalui proses kebetulan tetapi dilakukan dengan rancangan terstruktur termasuk penemuan anti virus ZIKV. Data membuktikan bahwa sofosbuvir layak dikembangkan lagi untuk menjadi senyawa anti-ZIKV yang baik dan diperjual bebas agar masyarakat yang terkena zika virus dapat di minimalisir.

\section{Daftar Pustaka}

A. R. Salehuddin et al., Zika virus infection and its emerging trends in Southeast Asia, Asian Pac. J. Trop. Med., Mar. 2017, vol. 10, no. 3, pp. 211-219.

E. D. Micewicz, R. Khachatoorian, S. W. French, and P. Ruchala, Identification of novel small-molecule inhibitors of Zika virus infection, Bioorg. Med. Chem. Lett., Feb. 2018, vol. 28 , no. 3, pp. 452-458,

C. W. Tan, I.-C. Sam, W. L. Chong, V. S. Lee, and Y. F. Chan, Polysulfonate suramin inhibits Zika virus infection, Antiviral Res., Jul. 2017, vol. 143, pp. 186-194,.

K. M. Bullard-Feibelman et al., The FDA-approved drug sofosbuvir inhibits Zika virus infection, Antiviral Res., Jan. 2017, vol. 137, pp. 134-140,. 
N. Mumtaz et al., Cell-line dependent antiviral activity of sofosbuvir against Zika virus, Antiviral Res., Oct. 2017, vol. 146, pp. 161-163,.

Zoy Jing and Pei-Yong Shi. Strategies for zika drug discovery, Antiviral., Current opinion in virology 2019, 35:19-26.

www.ceritakecil.com/tokoh-ilmuwan-dan-penemu/Alexander-Fleming-3 